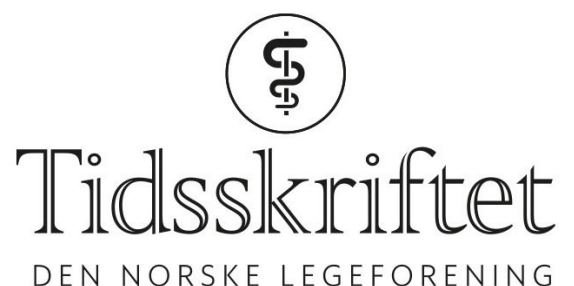

\title{
Nevrolitteraten som gikk i krigen
}

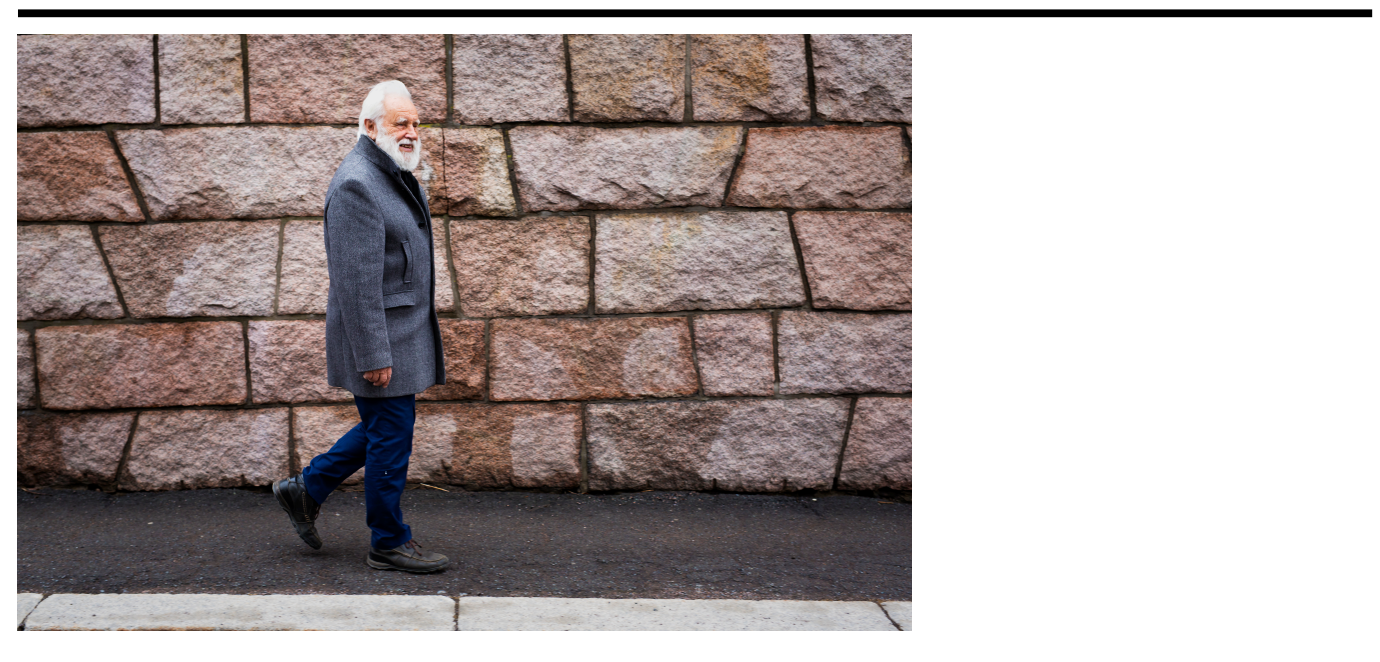

INTERVJU

MARIT TVEITO

Alderspsykiatrisk avdeling Diakonhjemmet Sykehus

Ragnar Stien synes han lærte mest om seg selv da han, iført skuddsikker vest, bygde en sykehusavdeling for ryggmargsskadede i Sarajevo. Nå bruker han tid på å lure på hvorfor Shakespeare lot en mann dø ved å få gift i øret. 


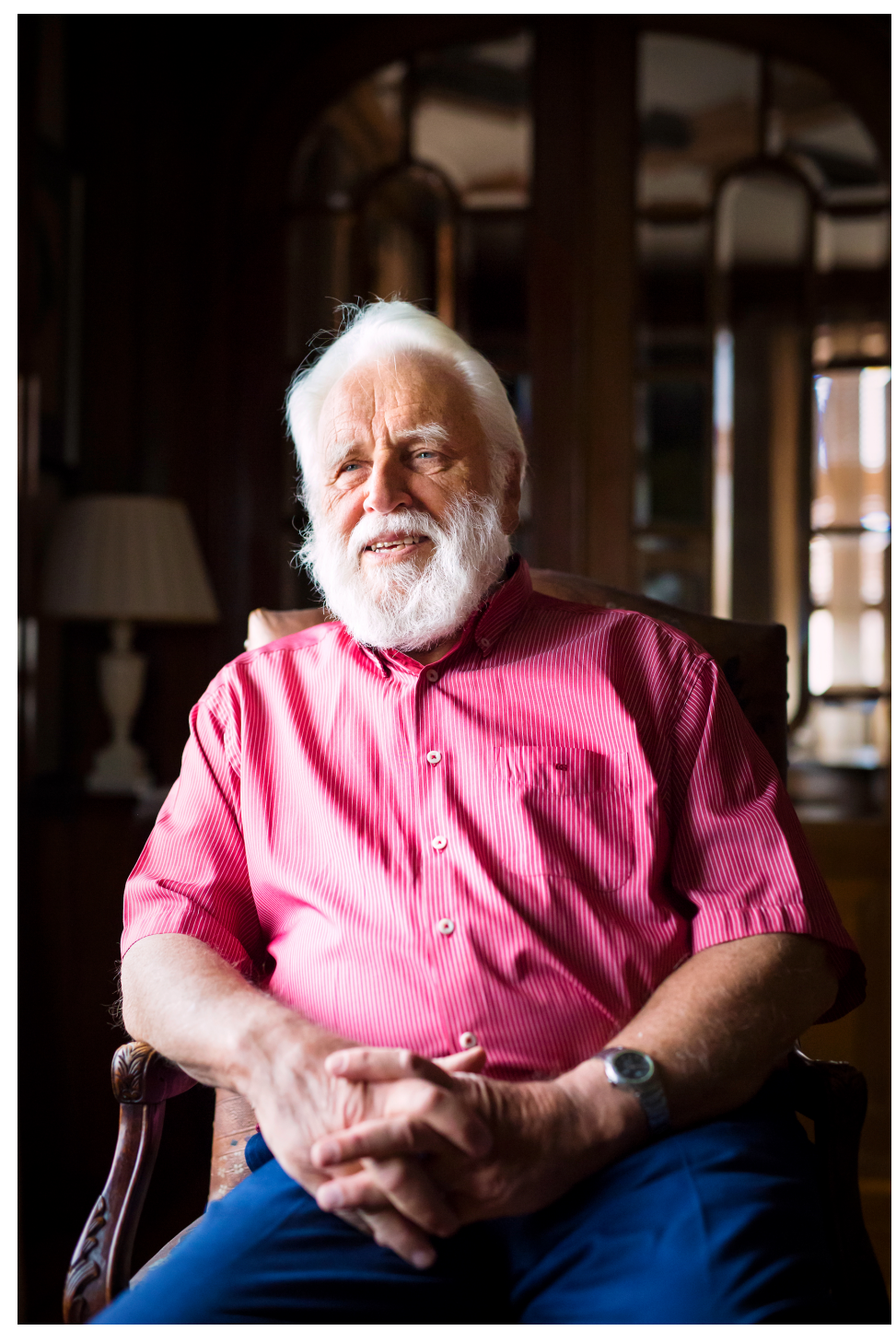

Ragnar Stien blir beskrevet som en raus og ruvende mann. I nevrologifaget har han vært en markant skikkelse innen nevrourologien og har bygd opp fagfeltet. Han er kjent for å være raus med kunnskap, mat og vin, og ekteparet Stien inviterer ofte til selskap i sitt vakre hjem, som er fylt med bøker og bilder. Stien ruver også i rommet, nesten $190 \mathrm{~cm}$ høy og kraftig. Han beskrives av en god venn som en «bamseperson».

Med en interesse for litteratur og historie som må sies å være over middels virker ikke medisinen som noe opplagt valg. Stien har vært leder for Den norske nevrolitterære klubb, er med i Det norske Shakespeareselskap og har nylig gått av som formann i Bibliofilklubben.

- Hva slags klubb er det?

- En klubb for særinger som liker å samle på bøker. Det er en elitistisk gruppe på 33 medlemmer. Klubben er hundre år gammel. Folk samler på de rareste ting, så det er en artig forsamling.

- Hvorfor ble du lege?

- Jeg hadde tenkt å bli kjemiker, men fant ut at jeg likte å jobbe med mennesker og valgte derfor medisinen. Det har jeg aldri angret på, jeg har hatt et fabelaktig yrkesliv. Jeg har tenkt på det mange ganger - hvilket privilegium jeg har hatt. Som lege treffer man så mange interessante mennesker. Jeg hører til et fagfelt hvor vi er nødt til å ha god tid til pasientene. Du kan ikke bruke et kvarter og kalle det en konsultasjon. Pasientene er takknemlige fordi de blir tatt ordentlig hånd om. De åpner seg på en annen måte når man setter av tid. Jeg har lært mye av pasientene mine.

- Du er glad i å lære? 
- Hvis jeg treffer noen som kan noe, vil jeg gjerne ha del i det.

\section{Rebusløser}

Stien har likt at kunst og medisin møtes.

- Jeg har aldri angret på at jeg valgte nevrologien. Jeg har legning for det, tror jeg. «En rebusløser» var det noen som kalte meg. Det er derfor jeg samler på kriminalromaner. Hvis du leser, vil du støte på problemstillinger som har med faget å gjøre, nesten uansett hva man jobber med. Så får man nesten et lite forskningsprosjekt i fanget. Hvorfor har Jo Nesbø tatt med Fahrs syndrom i Snømannen? Det skulle jeg gjerne ha snakket med ham om. Du vet sikkert ikke hva syndromet handler om?

- Nei, det stemmer.

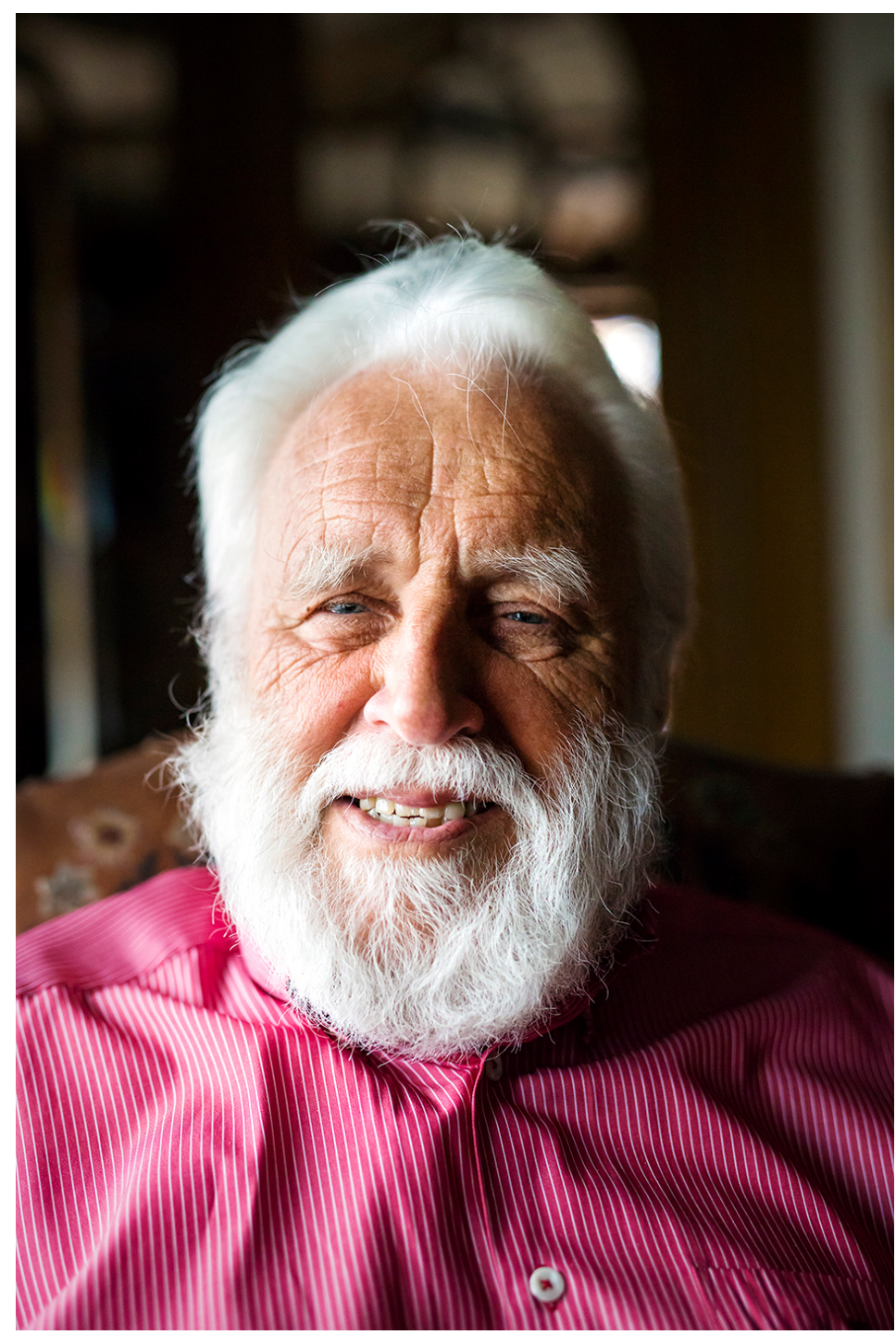

- Få mennesker gjør det. Lurer på hvor Nesbø har det fra, sier han og legger til: - Hva med litteratur hvor man tar livet av noen ved å helle gift i øret? Enhver doktor vet at det ikke vil virke. Da måtte det være noe heftig nervegift som ikke fantes på Shakespeares tid. Det har jeg lurt mye på, såpass mye at min kone har sagt at William må flytte ut av leiligheten vår.

- William Shakespeare?

- Jeg har publisert litt, og den artikkelen som blir sitert oftest, handler om Shakespeare og parkinsonisme. Den er på bare én side, men jeg har åpenbart truffet en nerve. Shakespeare omtaler faktisk typisk parkinsonisme to-tre steder i skuespillene sine. Det har vært en kuriositet i nevrologiens historie at parkinsonisme ikke var beskrevet før i 1817. Når man ser litt nøyere etter, visste Shakespeare at tilstanden ble kalt «shaking palsy». I essayet om sykdommen som Parkinson skrev, nevner han faktisk at sykdommen hadde hatt ulike navn tidligere. Men vi snakket jo egentlig om kriminalromaner? 


\section{Ragnar Stien}

Født 12. februar 1938

Cand.med. Universitetet i Oslo 1964

Spesialist i nevrologi 1975

Leder av Norsk nevrologisk forening 1990-93

Medlem av landsstyret i Legeforeningen 1996-2003

Stifter av Den norske nevrolitterære klubb

Grunnlegger av medlemsbladet Axonet

- Ja, vi gjorde jo det.

- Jeg samler spesielt på kriminalromaner med nevrologisk innhold. Jeg samler også på kriminalromaner som er skrevet av nevrologer. Jeg vet om 48 stykker.

- Du samler også på kunst?

- Nei. Han drar litt på det. - Kunstsamler vil jeg ikke kalle meg. Jeg har kjøpt kunst som jeg liker. Boksamler, derimot ...

- Hvor mange bøker har du?

- Jeg har et kontor og har vel omkring 3 ooo bøker der.

\section{Venting foran dodøren}

- I medisinen er det de ryggmargsskadede som har fått oppmerksomhet fra deg?

- Ja, det var en pasientgruppe jeg fikk stor omsorg for. Det dreide seg oftest om unge menn som hadde vært utsatt for en ulykke. Vi greide å rehabilitere dem til å sitte i rullestol, men det hjelper ikke hvis man bare sitter foran dodøren og venter på neste tømming. Jeg skjønte etter hvert at det var manglende kontroll over endetarm, blære og seksualorganer som var problemet, ikke det at de ikke kunne gå. Det er nedverdigende å lekke. Man kan godt si at man er ryggmargsskadet, men at man tisser på seg, det er ikke noe særlig. Jeg ville jobbe med det som var viktig for folk.

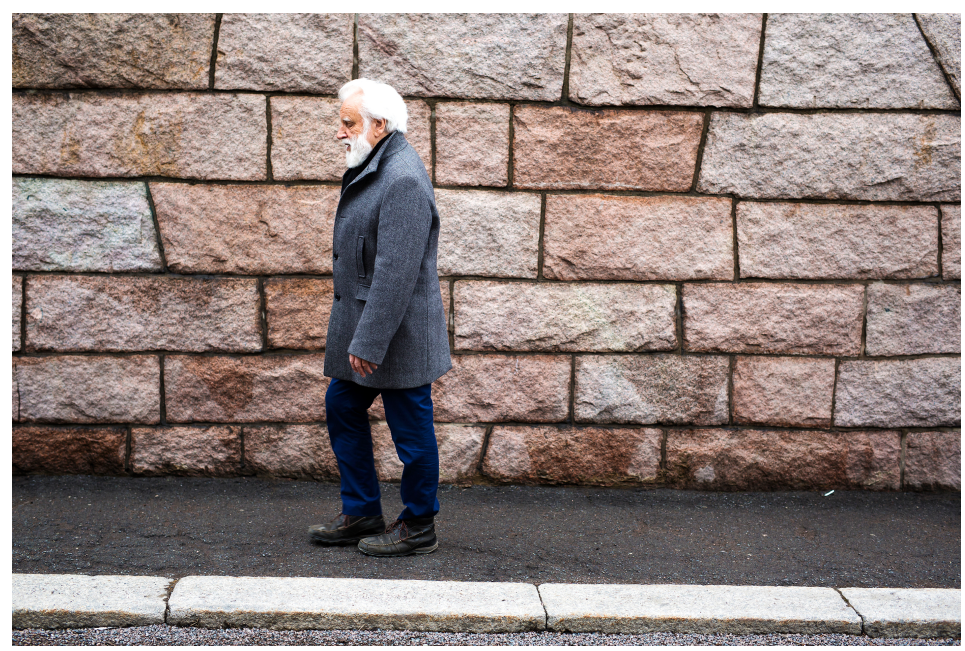

Han fortsetter: - Da Nansen var ambassadør i London, møtte han George Bernhard Shaw i et selskap. Nansen var en selskapsløve og en hit i selskapsverdenen i England. Shaw hadde stadig migreneanfall og var kjent for å være sur, grinete og vanskelig. Da han fikk høre at Nansen hadde gått på ski over Grønland, spurte han om hvorfor han gjorde slikt når ingen ennå hadde funnet et godt middel mot hodepine, forteller Stien.

- Shaw hadde et poeng. I medisinen må vi interessere oss for det som har betydning for pasientene. Så jeg reiste til Stoke Mandeville Hospital i England, der de var langt fremme på dette feltet. Jeg lærte mye. Da jeg kom hjem, fikk jeg være med på å opprette et laboratorium 
for nevrourologi. I Danmark hadde de allerede en slik avdeling, og jeg jobbet der en vinter også. Det ble mitt arbeidsfelt resten av mitt yrkesliv.

\section{Papirfly}

- Det virker nesten som arbeidslivet bare har vært en fest?

- Det har det for så vidt vært, men ikke alltid. Jeg må si at jeg er glad jeg er pensjonist. Jeg jobbet lenge ved Rikshospitalet, men kom etter hvert til Ullevål universitetssykehus. Der ble jeg sjef. Det skulle jeg jo aldri vært, ler han.

- Jeg hadde ikke problemer med personalet eller faget, men administrasjonen este noe voldsomt ut i løpet av den tiden jeg var der. Den besto av tre personer da jeg begynte, men var økt til 21 da jeg sluttet, hvorav 20 sykepleiere og en sosionom.

Han sukker. - Hva gjør så mange mennesker? De flytter papirer. Og hva slags papirer flytter de? Papirer som kommer fra oss som gjør jobben og vet hva vi holder på med. Jeg sier uten videre at halvparten av tiden min som avdelingssjef måtte jeg bruke på tøv. Jeg skrev planer og svarte på brev. Når jeg blir utsatt for slikt, kommer det frem noen dårlige sider hos meg. Jeg blir veldig ironisk, og det fører lite godt med seg. Jeg svarte en gang administrasjonen at jeg ville brette papirfly hvis jeg fikk flere tøvete brev. Det likte de selvfølgelig ikke, det skulle nå bare mangle. Jeg laget et organisasjonskart over Ullevål sykehus, det var bare ment som en morsomhet. Folk syntes det var vittig og hengte det opp på oppslagstavlene. Det skapte heller ingen goodwill for meg hos administrasjonen. Kort sagt, jeg er ikke så egnet til akkurat det der.

- Nå er det en stund siden du har jobbet klinisk?

- Jeg sluttet så fort jeg kunne. Jeg hadde sluttet før hvis jeg hadde hatt muligheten. Jeg mistrivdes som avdelingssjef. Jeg hører av folk i arbeid at det ikke er blitt noe bedre på sykehusene. Det er heller blitt verre.

- Hva tenker du om fremtiden for dine yngre kolleger?

- Jeg er sikker på at vett og forstand kommer til å overta igjen. Man må bli kvitt alle sykepleierne som har laget seg en karrierestige bort fra pasientene og inn i kontorene. Og så har vi blårussen som ikke får jobb i det private næringslivet, de skal også inn og styre. De færreste leger er verdensmester innen et fagfelt, men mange er norgesmestere. Det blir feil å bruke tid på å skrive rapporter til en administrasjon som ikke forstår hva vi driver med. Vi greier å ta oss av de fleste problemer som oppstår i en god avdeling. Jeg var et år i krigen i Bosnia. Det å jobbe inne i en omringet by, hvor man kunne bli beskutt, stiller en del krav til hvordan man håndterer den daglige situasjonen. Jeg fikk respekt for militær orden. Jeg hadde ansvar og jeg hadde myndighet.

\section{Skuddsikker vest}

- Hvorfor reiste du til Sarajevo?

- Byen var omringet, og på Lillehammer samlet man inn penger for å hjelpe den tidligere OL-arrangøren. Det ble mange penger, og de spurte de lokale myndighetene hva de ønsket seg. Svaret var: En avdeling for ryggmargsskadede. Mange var blitt beskutt og truffet i brysthøyde, med påfølgende skader. Ordføreren i Lillehammer visste ikke egentlig hva en slik avdeling besto av og henvendte seg til sjefen for nevrologisk avdeling på Lillehammer sykehus. Han spurte meg, som hadde jobbet lenge i fagfeltet. Jeg svarte kjekt at jeg skulle finne noen. Men så var det ikke så lett å finne noen som ville reise. De hadde små barn, fikk ikke lov av ektefellen og jeg vet ikke hva. Så tenkte jeg at jeg fikk gjøre det selv.

- Barna dine var store?

- Ja, de var voksne og greide seg godt selv. Nå er de blitt så voksne at de regner på pensjonspoeng. 
- Og så gikk turen til Sarajevo?

- Ja, det var litt av en tur. Vi fant en gammel bygning på et sykehusområde og fikk plass til 56 senger. Jeg lærte mye om meg selv. Du erfarer at du kan takle vanskelige situasjoner. På et skilt over døren vår sto det «Don’t crack under pressure».

- Du jobbet med skuddsikker vest?

- Det var en del av forsikringsavtalen. Hvis jeg ble skutt uten, ville ikke de hjemme få noen erstatning. Vi sov på gulvet, litt unna vinduene.

- Du er risikovillig?

- Jeg vet ikke. Jeg vil ikke si det. Jeg påtok meg en jobb og lyktes. Jeg jobbet under Røde Kors. Det var de som hadde infrastrukturen, og der er det mange regler å forholde seg til. Hvis vi hadde fulgt regelverket, hadde vi aldri fått til noe.

- Hvordan har det gått med avdelingen?

- Den finnes fortsatt. Jeg var der nede en tur - det ble et emosjonelt møte. Mange av dem vi lærte opp, var der fremdeles. Huset står der, med norske bilder på veggene. Norske kunstnere donerte bilder til Olympic Aid, og ikke alle var loddet ut. Vi fikk med oss en del til sykehuset. Det var en lærerik tid, og jeg tenkte mye over hvordan helsevesenet bør organiseres.

- Hva slags ideer og innsikt tok du med deg?

- Som leder i helsevesenet har du ansvar, men ikke myndighet. Ta for eksempel budsjettene. Du trenger ikke en BI-utdanning for å regne ut tariffestede lønninger, og da er tre firedeler brukt opp. Så vet du også hvor mye som går til å drifte avdelingen. Og da er det ikke noe igjen. Jeg sa ved en anledning - da jeg hadde fått budsjettet for det kommende året - at vi kom til å gå tre millioner kroner i underskudd. Pasientene er jo der uansett. Svaret fra administrasjonen var at jeg hadde ansvaret for å få budsjettet til å gå opp og at det måtte gjøres endringer i driften. Da jeg foreslo å kutte ut behandlingstilbudet som gjaldt en sykdomstilstand som var plagsom, men ikke dødelig, fikk jeg til svar at jeg ikke kunne gjøre endringer som gikk utover pasienttilbudet. Jeg kunne ikke bestemme noe, derfor kunne jeg heller ikke bry meg om budsjettet. Vi gikk tre millioner kroner i underskudd.

\section{Krusninger i overflaten}

- Du har også jobbet med forsikring?

- Ja, med risikovurdering for forsikringsindustrien. Det har vært lærerikt. Du får et annet perspektiv. Livsforsikring er ikke noe annet enn grundig medisinsk kunnskap pluss matematikk. Vi hadde utmerkede statistikere. Jeg skjønte jo etter hvert at det spiller liten rolle hvor høyt kolesterolnivå du har, hvor mye du mosjonerer eller hvor tung du er, med mindre du er altfor overvektig, da. I medisinen er vi opptatt av å forebygge hjerte- og karsykdom hos dem med høyt kolesterolnivå. Det er krusninger i overflaten. Hva er den viktigste faktoren når du skal vurdere risiko for uførhet og død? Vet du hva det er?

- Nei.

- Det er hva slags utdanning du har. Det slår mye ut. Hvorfor lever akademikere 10-15 år lenger enn dem som bare har grunnskole? Og hvorfor er halvparten av dem med kun grunnskoleutdanning uføre når de har fylt 50 år, når nesten ingen akademikere er det? Det burde interessere medisinerne. De faktorene som vi i helsevesenet er opptatt av, er kanskje ikke de viktigste for folkehelsen. Trivsel er viktigst.

- Du sa at du aldri har angret på at du ble lege.

- Nei, bare da jeg skrev strategiplaner, humrer han.

- Hva er du mest fornøyd med når du ser tilbake?

- Det er jo litt sært, men det som ga mest positiv tilbakemelding fra pasientene, var at jeg 
skaffet dem barn. Ryggmargsskadede menn mangler ejakulasjonsrefleks, og vi laget et opplegg for å hente ut sæd. Det ble kanskje 30-40 barn ut av det. Det er de mest takknemlige pasientene jeg har hatt.

\section{Billige sykehussenger}

- Du har fylt 80 år. Er det noe du fortsatt har lyst til å utrette?

- Jeg har forberedt meg på å bli pensjonist. Egentlig gjør jeg de samme tingene som da jeg var i full jobb. Jeg skriver unyttige ting som folk ikke behøver å lese. Jeg holder foredrag om historie og nevrolitteratur. Forskjellen er at jeg jobber uendelig mye langsommere enn jeg gjorde før, sier han.

- Det å være pensjonist i dette kongeriket er noe av det beste man kan være. Apanasjen kommer hver måned, og du kan gjøre akkurat det du vil. Det eneste som er vanskelig med å bli eldre, er sykdommene som kan følge med. Men det er et helseproblem, ikke et aldersproblem.

Han fortsetter:- Man snakker om eldreomsorg. Eldre som meg trenger ingen omsorg. Vi har det så fint som vi kan ha det og holder liv i hoteller og reisebyråer. Syke eldre er noe helt annet. De får jo knapt ligge på sykehus. Det har ergret meg. Eldre har ofte flere problemer, men blir sendt raskt hjem, sier han.

- Selve overnattingen på sykehuset er ikke dyr, kanskje noe av det billigste i landet. Jeg regnet på det på min egen avdeling. Jeg tok med bare selve driften, og da kom døgnprisen på 156 kroner med full pensjon. Så ble det sagt at prisen var 5 ooo kroner i døgnet. Det er bokholderi. Man tar alle sykehusets utgifter for et år og deler på antall overnattinger i året. Det blir ikke riktig. Når det kommer en pasient inn med helikopter og mange jobber med denne pasienten i noen døgn, koster det selvfølgelig mye. Men når fru Jensen ligger og venter på å komme på sykehjem, så er prisen rimelig. Jeg har sagt dette i alle år, men det er ingen som hører på meg. Det er helsepersonell og utstyr som koster penger, og det skal jo være der uansett. At gamle mennesker blir sendt hjem til en utrygg tilværelse når bare noen få dager ekstra kunne gitt dem tid til å komme seg skikkelig, har jeg vondt for å forstå.

- Du virker jo sprek, men er du redd for å bli gammel og syk?

- Hvem er ikke det?

- Tar du noen forholdsregler?

- Nei, tiden i forsikringsbransjen har ført til en viss nihilisme. Det er lite som spiller noen rolle så lenge jeg trives og har det artig. Da holder jeg meg frisk. Litt plager følger med årene, men syk er jeg ikke. Jeg har jobbet med alvorlig syke mennesker med store funksjonshemninger hele mitt liv. De har vist meg hvordan man kan håndtere et hverdagsliv med store utfordringer.

- Er det verre å se på hvordan helsevesenet behandler eldre pasienter når man blir eldre selv?

- Det setter det i et nærere perspektiv. Du skjønner det bedre.

- Hva kan sykehusene gjøre for at det skal bli bedre å være gammel og syk?

- Vi må ta vare på de eldre. Trygghetsfølelsen i sykehus skal man ikke kimse av, den har en helsefremmende effekt. Skriver man folk ut for tidlig, blir de syke på nytt. Gamle bør få ligge litt i fred på sykehus. Det koster ikke så mye.

Publisert: 26. juni 2018. Tidsskr Nor Legeforen. DOI: 10.4045/tidsskr.18.0299

(C) Tidsskrift for Den norske legeforening 2020. Lastet ned fra tidsskriftet.no 